Article

\title{
The Influence of Word of Mouth on Tourism Destination Choice: Tourist-Resident Relationship and Safety Perception among Mainland Chinese Tourists Visiting Macau
}

\author{
Ivan Ka Wai Lai ${ }^{1}$, Michael Hitchcock ${ }^{2}$, Dong Lu $^{3, *}$ (D) and Yide Liu ${ }^{4, *}$ (D) \\ 1 Faculty of International Tourism and Management, City University of Macau, \\ Avenida Padre Tomás Pereira, Taipa 999078, Macau, China; ivanlai@cityu.mo \\ 2 Institute for Creative and Cultural Entrepreneurship, Goldsmiths, University of London, \\ New Cross, London SE14 6NW, UK; m.hitchcock@gold.ac.uk \\ 3 School of Business, Sichuan Normal University, Chengdu 610101, China \\ 4 School of Business, Macau University of Science and Technology, Taipa 999078, Macau, China; \\ ydliu@must.edu.mo \\ * Correspondence: dlu@sicnu.edu.cn (D.L.); ydliu@must.edu.mo (Y.L.)
}

Received: 29 May 2018; Accepted: 15 June 2018; Published: 18 June 2018

\begin{abstract}
The growth of urban tourism has the potential to increase tourist-resident tensions that limit the sustainable growth of tourism in many destination cities. Visitors' perceptions of poor tourist-resident relationships and conditions of safety may have an impact on their attitudes, especially with regard to trip satisfaction. This study investigates the roles of tourist-resident relationship and safety perception on the relationship between service quality, trip satisfaction, and word of mouth (WOM). The results of this empirical study $(n=386)$ show that the tourist-resident relationship and safety perception have significant effects on trip satisfaction, but only safety perception reveals a significant effect on WOM. Furthermore, the results also indicate that the tourist-resident relationship and safety perception moderate the relationship between service quality and trip satisfaction, and that the tourist-resident relationship also moderates the relationship between trip satisfaction and WOM. An understanding of these mechanisms can help governments to create appropriate policies to support the sustainable development of tourism and promote their tourism industries by fostering tourists' WOM.
\end{abstract}

Keywords: tourist-resident relationship; safety perception; trip satisfaction; word of mouth; Chinese tourists

\section{Introduction}

In Asian urban destinations, large increases in inbound tourism were generally seen as unproblematic and the critical literature on the subject is limited as compared with city destinations in other regions, notably Europe. However, this has changed dramatically over the last few years, especially with regard to Asian tourism cities. Recent studies have indicated that residents were starting to complain about the annoyances associated with urban tourism [1] and that those annoyances affect the tourist-resident relationship [2]. But on the tourist side, it remains unclear what impact a strained tourist-resident relationship has on tourist behavior because relatively few studies have been undertaken in this area, especially in Asian tourism cities. Since the tourist-resident relationship is one of the sustainability issues regarding the social aspect of tourism development, this study addresses this gap and pays particular attention to variables such as tourism satisfaction and word of mouth (WOM). 
Personal safety during the trip is the top motivational attribute in attracting tourists to visit a destination [3]. Destinations considered to be unsafe by tourists may not be considered to be suitable holiday choices [4] and it is clear that violent attacks do strongly influence the choice of destination in a negative way. Previous studies only indicated that the choice of destination would be affected by the safety information from media [5]. When a tourist visits a destination, he/she will have an experience concerning the safety conditions in that destination, but the effect of his/her safety perception on his/her behavior toward the destination is still unclear. Thus, the perception of safety may be said to be closely linked to sustainability issues related to tourism development in urban destinations. So, understanding tourist behavior in relation to the perception of safety in a given trip experience is important, not least because it helps with the planning of tourism development.

When planning a vacation, one key aspect for him/her to make the choice is WOM, which mainly concerns information and referrals from friends, family, and other acquaintances [6]. Many previous studies have examined the influence of WOM on destination choice [7] and have shown that service quality and trip satisfaction are sources of WOM recommendation [8]. However, what remains less clear is how the tourist-resident relationship and safety perception influence trip satisfaction and how these are related to WOM.

The objective of this study is to examine the impacts of the tourist-resident relationship and safety perception on the relationship between service quality, trip satisfaction, and WOM recommendation. The results of this study provide a more detailed understanding of how these processes work and will hopefully support the creation of more effective governmental policies as positive WOM is a very important, credible, and effective marketing tool for attracting new tourists in order to develop sustainable tourism marketing. This study also provides a contribution to the theory of the tourist-resident relationship [9] with an emphasis on a more holistic understanding that takes on board the perspective of tourists' perceptions and not just those of residents, not least because there is a lack of empirical research in investigating how tourists perceive and evaluate their impacts [10].

\section{Literature Review}

\subsection{Tourist-Resident Relationship}

In order for tourism to flourish, there is a need to manage the relationship between residents and tourists in a sustainable manner [11]. What makes this challenging in urban areas is that residents and tourists are often sharing the same physical spaces with very different objectives in mind. Residents, unless engaged in the provision of tourism services, are often simply following their daily lives whereas tourists seek leisure experiences involving monetary and non-pecuniary exchanges that impact on residents' lives often unintentionally and without the tourists realizing it [12]. What is also significant is that local residents can sometimes accuse tourists, especially if foreign born, as having a negative influence on their lives even when there is little evidence to support these claims [13]. In the eyes of residents, tourism can also become the scapegoat for a range of social ills whether or not the visitors are really responsible for them [13]. In these contexts, it may be helpful to follow Ap [14] with regard to his use of social exchange theory to analyse the resident-tourist relationship.

In some cases residents may have quite a positive view regarding the role of tourism that is related to a sense of increased prosperity and enhanced job opportunities; even increases in the price of land, property, goods, and services can be seen in a positive light [15], especially when residents are the beneficiaries. By the same token, tourists may view their role positively in terms of their contribution to the economy of the destinations they visit and may perceive their impact on the host community in terms of being beneficial or at worst as neutral [12].

However, when tourists are seen making use of spaces that were originally designed for the local community such as parks, gardens, and beaches, relations may become strained with residents sometimes confronting visitors within these shared spaces [16-18]. Furthermore, residents may also resent the impact that tourists have on their environment with complaints about vandalism and littering 
being commonplace and, to a lesser extent, noise pollution [19], and even stolen public resources [20]. The majority of previous studies of resident-tourist interrelationships have focused on examining local residents' attitudes to tourism and tourists, and thus there are comparatively fewer studies on how visitor behavior is influenced by the tourist-resident relationship. However, tourists visit and spend money in these residents' communities, and many increasingly favor sustainable tourism development [21], so it is necessary for us to examine tourists' attitudes toward an urban destination in different levels of the tourist-resident relationship.

\subsection{Safety in a Destination}

With regard to urban destinations, tourists' safety is recognized as potentially posing a global problem for sustainable tourism [22]. A tourist destination only can be developed in a situation that offers a high level of safety [23] and consequently safety is an essential key to sustainable tourism [24] that merits further scrutiny, so there is also a need to examine tourists' attitudes toward an urban destination on different levels of safety in that destination. Ryan [25], for example, observed that terrorism, violence, and crime can lead to grave consequences for both tourists and destinations.

Tourists have been targeted to advance various political causes, and one of the most widely known outrages occurred at Luxor in Egypt in 1997 where 62 people lost their lives at the hands of terrorists leading to tourists factoring in the risk of terrorism into their choice of destinations [26]. After the 11 September attacks in the United States, tourists become even more concerned about the safety of destinations. Seabra, Dolnicar, Abrantes, and Kastenholz [27] report over 10 percent of tourists from Spain, Portugal, Germany and Brazil being very concerned about terrorism and turmoil when considering international trips. The above cases showed that tourists are worried about the risk of terrorist attacks and, in order to reduce their exposure to risk, they will cancel their travel plans or change their destinations.

Violence concerns the use of physical force intended to hurt someone or something [28]. Violent attacks on tourists frequently happen in many destinations. For example, recently, gang violence in Mexico threatened to affect most popular tourist spots [29]. As might be expected, serious acts of violence committed against tourists can cause significant declines in tourism demand [30]. Destinations which exhibit high levels of violence are unlikely to be attractive to tourists.

Aside from terrorist attacks and violence, crime is another safety issue that limits tourist flows [31]. Previous studies have indicated that visitors are more likely than local residents to be the victims of crime [32], not least because tourists are unfamiliar with the local laws, do not know how to report the crimes, and are not willing to press charges against criminals. Since there is high profit from a tourist and a low risk of conviction [33], these potentially make tourists a target of crime.

\subsection{Research in Service Quality, Satisfaction, and Word of Mouth (WOM)}

Perceived service quality is seen as a critical antecedent of both customer satisfaction [34] and WOM [35]. On the other hand, tourists with higher levels of trip satisfaction are willing to give a more positive WOM [36]. Both tourist satisfaction and WOM are important for sustainable tourism [37]. The relationships between service quality, customer satisfaction, and WOM are well confirmed in many previous studies [38,39].

Conceptually, service quality is defined as a global judgment or attitude relating to the overall excellence or superiority of service [40]. In order to evaluate service quality, more than 100 measurement scales have been developed in different hospitality and tourism sectors in the last 30 years [41]. Some researchers employed or extended the well-known SERVQUAL approach [42] with others developing sub-dimensions of service quality [43]; some researchers based the rating of attributes of service quality $[44,45]$, whereas others have employed single attribute-based variables to assess the overall outcomes of service quality [46]. The most cited single attribute-based scale is Cronin, Brady, and Hult's [47] measurement in which they used "excellent", "superior", and 'high standards' to measure overall service quality. Whatever the measurement scales that 
researchers have employed, their results generally confirmed the positive relationship between service quality and customer satisfaction.

WOM is a form of interpersonal communication among consumers that have a significant effect on consumer suggestion formation and purchasing decisions [48]. Previous empirical studies have already shown that service quality is one of the determinants affecting WOM recommendation (e.g., [49]) and when a tourist experiences good tourism services at a destination, he/she will recommend this destination to his/her friend and relatives. Therefore, good quality tourism service can generate positive WOM with regard to a given destination.

One of the aims of sustainable tourism is to increase tourist satisfaction [50] with satisfaction being conceptualized in different ways [51], and according to this different types of satisfaction have been defined such as either a transaction-specific measure [52] or an overall evaluation [53]. Oliver [54] defined satisfaction as the summary psychological state resulting when the emotion surrounding unconfirmed expectations is coupled with a prior feeling about the consumer experience. In line with Oliver [54], Bloemer and Odekerken-Schroder [55] perceived satisfaction as a post-consumption evaluation (a pleasurable level of consumption-related fulfillment), but for tourism studies, researchers generally used overall satisfaction to measure tourists' levels of satisfaction (e.g., [8]). Baker and Crompton [38] have defined satisfaction as an experiential quality related to the emotional well-being generated during and after the visit experience. Thus, maintaining a high level of tourist satisfaction is considered to be an integral part of what makes it sustainable [56].

Numerous studies have examined the link between tourist satisfaction and WOM publicity and the general consensus is that, when the tourists feel satisfied with the services, products, and other resources that they experience in the destinations they visit, then positive WOM effects to relatives and/or colleagues are enhanced (e.g., [38,57]). Tourist satisfaction, which is linked to service quality, also plays a mediating role between perceived service quality and WOM on a tourism destination. Therefore, improving service quality is a way of developing sustainable tourism since it can increase tourist satisfaction which can be disseminated by more effective tourism marketing [58].

\section{Research Method}

The above literature reveals that the relationships between service quality, satisfaction, and WOM are well-established. Therefore, this study attempts to make a contribution by examining the influence of the tourist-resident relationship and safety perception on perceptions of service quality, trip satisfaction, and WOM with regard to a given urban destination.

\subsection{Research Hypothesis}

The residents' attitude toward tourists is an important factor in the overall attractiveness of a destination [59] and one of the attributes motivating tourists to make a visit is 'interaction with local people' [60]. This interaction generates a rewarding experience for tourists [61]. Tourists care about the responses from the residents that they meet and in cases where they experience a good relationship they may be more be satisfied with the trip and may be more be willing to recommend it by WOM as one of their significant travel expectations has been realized. Accordingly, the following hypotheses are proposed:

Hypothesis 1a (H1a). The tourist-resident relationship that a tourist experienced influences his/her trip satisfaction in a destination.

Hypothesis $\mathbf{1 b}(\mathbf{H 1} \mathbf{b})$. The tourist-resident relationship that a tourist experienced influences his/her WOM recommendations regarding a given destination.

Previous studies have also indicated that tourists' perception of safety is highly likely to influence their behavior, especially with regard to choice of destination $[28,62]$. Other than the choice of 
destination, the safety of a destination also has a big impact on the level of satisfaction with a tourist trip [63]. Yoon and Uysal [64] stated that safety is one of the tourists' motives which affect tourists' tendency to be loyal to a destination. Therefore, a positive perception of safety encourages tourists to experience greater trip satisfaction [63], but tourists will not be likely to recommend this destination to others if they felt unsafe in the destination [32] and thus a second set of hypotheses are proposed:

Hypothesis 2a (H2a). The safety perception of a destination that a tourist experienced influences his/her trip satisfaction with regard to that destination.

Hypothesis $\mathbf{2 b}(\mathbf{H} \mathbf{2 b})$. The safety perception of a destination that a tourist experienced influences his/her WOM recommendations regarding that destination.

Tourism services provide the cultural interaction between residents and tourists [65]. Visitors desire to experience different lifestyles and people in a destination, so the friendliness of local people becomes a source of tourists' attachment [66]. Some researchers have even argued that the social attachment with local people is greater than physical attachment (such as climate and nature) in all cases that they studied [67]. On the other hand, in tourism destination cities, many residents work in the tourism sector serving tourists in a variety of ways. So cultural interaction occurs in a service encounter situation [68]. Since emotions have a direct impact on service-quality judgments [39], when a tourist has a good experience of interaction with local people such as hotel employees, the impact of service quality on trip satisfaction may be higher and, accordingly, the impact of service quality on WOM recommendation may be higher too. Furthermore, the impact of trip satisfaction on WOM recommendation may be higher; and vice versa. Thus, the following hypotheses are proposed:

Hypothesis 3a (H3a). If a tourist perceives a good tourist-resident relationship, then the positive relationship between perceived service quality experienced in a destination and trip satisfaction with this destination will be stronger.

Hypothesis $\mathbf{3 b} \mathbf{b} \mathbf{H} 3 \mathbf{b})$. If a tourist perceives a good tourist-resident relationship, then the positive relationship between the perceived service quality experienced in a destination and WOM associated with the destination will be stronger.

Hypothesis $3 \mathbf{c}(\mathbf{H} 3 \mathbf{c})$. If a tourist perceives a good tourist-resident relationship, then the positive relationship between trip satisfaction with a destination and WOM with regard to this destination will be stronger.

Tourists like to feel safe and secure wherever they are [69] and thus it follows that service providers at a given destination should ensure that visitors feel well-protected [70]. During the trip, the tourists' emotional state will be influenced by their experiences not least because emotions impact upon consumer judgments [39]. Should a tourist worry about the safety of his/her luggage and belongings whether in hotels or restaurants, he/she will feel less satisfied with the services provided. This is because the provision of security is perceived by tourists as a basic service. On the other hand, when a tourist has a good experience of safety conditions, the impact of service quality on trip satisfaction may be higher and, accordingly, the impact of service quality on WOM recommendation may be higher. Thus, the impact of trip satisfaction on WOM recommendation may be higher and vice versa, and so the following hypotheses are proposed:

Hypothesis 4a (H4a). If a tourist perceives good safety conditions, then the positive relationship between perceived service quality experienced in a destination and trip satisfaction with this destination will be stronger.

Hypothesis $\mathbf{4 b} \mathbf{b} \mathbf{H} \mathbf{4 b})$. If a tourist perceives good safety conditions, then the positive relationship between perceived service quality experienced in a destination and WOM in this destination will be stronger. 
Hypothesis 4c (H4c). If a tourist perceives good safety conditions, then the positive relationship between trip satisfaction with a destination and WOM with regard to this destination will be stronger.

Based on the above hypotheses, a research model for this study is explained in Figure 1.

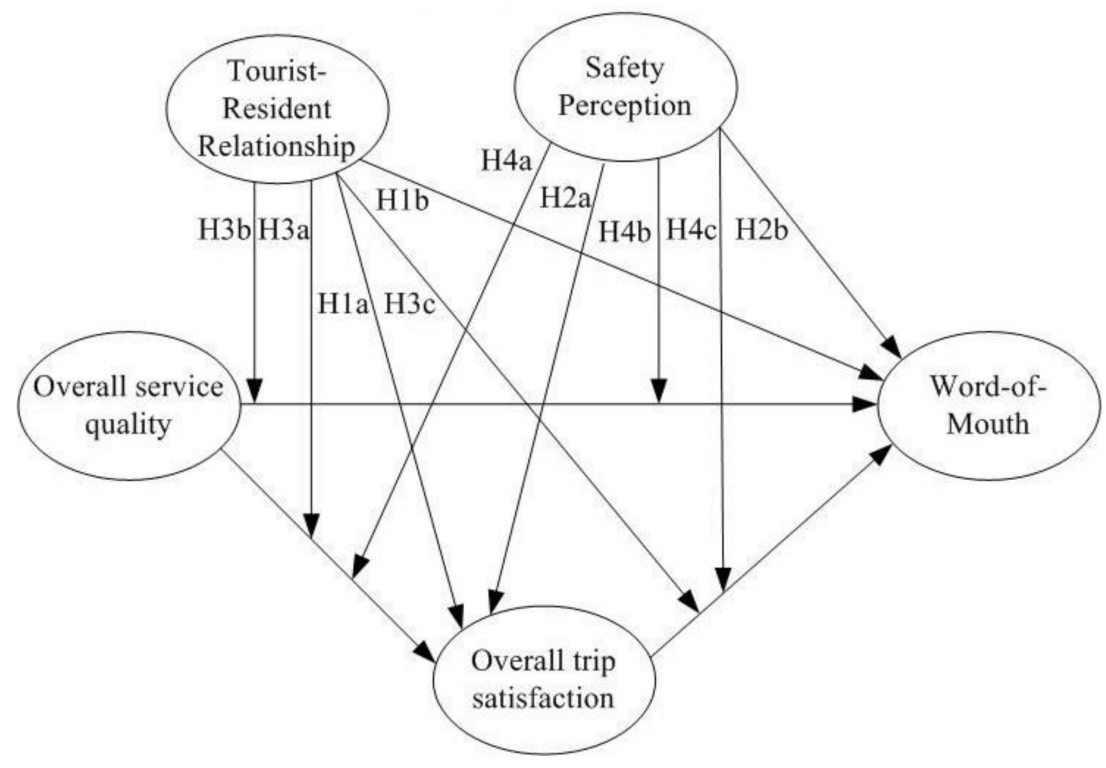

Figure 1. Research model.

\subsection{Research Instrument}

In this study, perceived service quality is the overall measure of quality that tourists experience in a destination and the measurable items are taken from Cronin, Brady and Hult's [47] research. Trip satisfaction is the overall satisfaction regarding a trip to a destination and the measurable items are taken from Bloemer and Odekerken-Schroder [55]. The WOM is an active form of advocacy for promoting a destination to friends and relatives and the measurable items are taken from Babin, Lee, Kim and Griffin [71]. Some modifications have been made to suit the specific characteristics of this case. The measurement of the tourist-resident relationship is based on three statements about residents' behavior (contact, show friendliness, and interact) toward the tourists. To capture the perception of safety, the responses in three key unsafe events (crime, violence, and terrorism) in a destination are measured in reverse statements. Table 2 shows the measurable items of the three constructs and two moderators.

\subsection{Questionnaire Design}

A questionnaire survey was used consisting of two sections with Section 1 containing 9 questions about perceived service quality, trip satisfaction, and WOM, as well as 6 questions about the tourist-resident relationship and perception of safety. Items were measured on a 7-point Likert-type scale ranging from 'strongly disagree' (1) to 'strongly agree' (7). In order to reduce the likelihood of common method variance, questions about the tourist-resident relationship and safety conditions were inserted between the measurable questions of perceived service quality, trip satisfaction, and WOM as recommend by Chang, van Witteloostuijn, and Eden [72]. Section 2 was used to gather contextual, general, and background information.

\subsection{Data Collection}

The subject of this study is Macau, a former Portuguese colony that reverted to Chinese control in 1999. Following the introduction of large-scale casinos from the USA and Australia, Macau became the 
world's premier gaming centre, outstripping Las Vegas in terms of revenue in 2007. In 2016, the total land area of Macau was approximately 30.4 square kilometers and the population approximately 650,000 [73]. In recent years, the city has become heavily congested with mainland Chinese tourists (20.69 million mainland Chinese tourists in 2017) [74]. Rapid tourism growth has created tension between the residents and tourists in terms of resource allocation and usage and environmental quality [75]. The tourism boom associated with gaming and cultural heritage has been accompanied by a rise in crime [76] and thus Macau was chosen to be the subject of the study because it faces a growth of urban tourism that may potentially increase tourist-resident tensions and generate personal safety problems.

The tablet-based survey in Chinese was administrated by two well-trained research assistants. It does not only save the cost and time but also prevent the occurrence of missing data. Data were collected by means of systematic sampling at 15 attraction points including the ruins of St Paul, Senado Square, A Ma Temple etc. at regular sampling intervals (every $15 \mathrm{~min}$ ) from 10 a.m. to 5 p.m. from July to August 2015. The sequence of 15 attraction points was randomly drawn from the tickets in a box (where each ticket has the name of an attraction point written on it). A filter question was asked to confirm whether or not respondents were mainland Chinese tourists to Macau. Then, the tourists were asked to answer the questionnaire in the light of their experience of their current visit. Since there were only 20 questions, respondents could easily complete the survey within $5 \mathrm{~min}$ and received a souvenir (cost around USD1). The short survey time could reduce the non-response bias due to time pressure. A total of 422 copies of the questionnaire were collected; however, 36 completed copies were found to be unusable because respondents used the same scale to evaluate most questions. So the net number of usable versions of the questionnaire was 386 . Table 1 shows the background information regarding the respondents.

Table 1. Demographics of respondents $(n=386)$.

\begin{tabular}{cccc}
\hline & & Frequency & Percent \\
\hline \multirow{2}{*}{ Gender } & Male & 184 & 47.7 \\
& Female & 202 & 52.3 \\
\hline \multirow{4}{*}{ Age } & 20 or under 20 & 13 & 3.4 \\
& $21-30$ & 112 & 29.0 \\
& $31-40$ & 129 & 33.4 \\
& $41-50$ & 111 & 28.8 \\
Education & Over 50 & 21 & 5.4 \\
& Secondary school level & 54 & 14.0 \\
& Undergraduate level & 281 & 72.8 \\
& Postgraduate level & 51 & 13.2 \\
\hline \multirow{2}{*}{ Income } & Less than USD1000 & 13 & 3.4 \\
& USD1000-2999 & 162 & 42.0 \\
& USD3000 or above & 211 & 54.7 \\
\hline \multirow{2}{*}{ Main purpose } & Business & 38 & 9.8 \\
& Visit relatives & 20 & 5.2 \\
& Vacation & 328 & 85.0 \\
\hline
\end{tabular}

\subsection{Analysis Method}

A partial least squares (PLS) analysis was performed using the SmartPLS v.3.2.6 package [77] because PLS is capable of maximizing the variance explained by dependent variables [78]. Another reason for using PLS is because this study involves the testing of moderating effects, so a PLS analysis is more appropriate [79]. Also, it is more robust when used with small sample sizes and non-normal data and when applying the bootstrapping [80], and thus the data in this study does not need to conform to the requirement of normality. According to the suggestion from Hair, Sarstedt, Ringle and Mena [81], bootstrapping was performed using 386 cases and 5000 samples to assess the moderating effects of the tourist-resident relationship and condition of safety as recommended. 
The fourth reason for using PLS is the type of outer model [82]. In this research model, safety perception is measured by three independent causes (crime, violence and terrorism) which do not need to be correlated. Since the research model consists of both formative and reflective constructs and PLS modeling allows the unrestricted computation of this kind of model [83], then PLS was used to achieve the above purposes.

\section{Findings}

\subsection{Reliability, Validity and Correlation}

Confirmatory factor analysis (CFA) was conducted to assess the construct validity and Table 2 indicates the descriptive statistics and factor loadings of each measurable item. Table 3 reports the values of the reliability, construct reliability (CR), and average variance extracted (AVE) for the study's constructs. All the values are above the minimum criterion (Cronbach's Alpha > 0.7, AVE >0.5, and $C R>0.7$ ), so the data has adequate reliability and a good convergent validity [84]. Table 3 also shows the correlation matrix, and that the square-root of each construct's AVE is greater than the correlations with other latent constructs, so the model meets discriminant validity criteria.

Table 2. Mean, standard deviation and factor loadings.

\begin{tabular}{|c|c|c|c|c|}
\hline & Measured Item & Mean & Std. Dev. & $\begin{array}{c}\text { Factor } \\
\text { Loadings }\end{array}$ \\
\hline SQ & Overall service quality (adapted from Cronin et al. [47]) & & & \\
\hline SQ2 & Overall, the tourism services offerings in Macau are of high quality. & 5.930 & 0.948 & 0.893 \\
\hline SQ3 & Macau maintains superior tourism services in every way. & 5.922 & 0.887 & 0.889 \\
\hline TS & Trip satisfaction (adapted from Bloemer and Odekerken-Schroder [55]) & & & \\
\hline TS3 & I am satisfied with my decision to visit Macau. & 5.650 & 1.240 & 0.851 \\
\hline WOM & Word of mouth (adapted from Babin et al. [71]) & & & \\
\hline WOM1 & I will encourage friends and relatives to visit Macau. & 5.870 & 1.079 & 0.909 \\
\hline WOM2 & I will recommend Macau to someone who seeks my advice. & 5.870 & 1.128 & 0.926 \\
\hline WOM3 & I will say positive things about Macau to other people. & 5.925 & 1.139 & 0.913 \\
\hline TRR3 & The residents in Macau are willing to interact with tourists. & 5.026 & 1.477 & 0.903 \\
\hline $\mathrm{SP}$ & Safety perception & & & \\
\hline SP1 & I don't feel worried about crime in Macau. & 5.759 & 1.155 & \\
\hline SP2 & I don't feel worried about violence in Macau. & 5.889 & 1.209 & \\
\hline SP3 & I don't feel worried about terrorist attacks in Macau. & 5.878 & 1.128 & \\
\hline
\end{tabular}

Note: (1) $\mathrm{SQ}$ = service quality; TS = trip satisfaction; WOM = word of mouth; TRR = tourist-resident relationship; $\mathrm{SP}=$ safety perception; (2) safety perception is a formative measure, so there are no factor leadings.

Table 3. Reliability, validity and latent variable correlations.

\begin{tabular}{ccccccccc}
\hline & Cronbach's Alpha & CR & AVE & SP & SQ & TRR & TS & WOM \\
\hline SQ & 0.872 & 0.921 & 0.796 & 0.463 & 0.892 & & & \\
TRR & 0.895 & 0.934 & 0.826 & 0.348 & 0.443 & 0.909 & & \\
TS & 0.845 & 0.907 & 0.764 & 0.496 & 0.685 & 0.642 & 0.874 & \\
WOM & 0.904 & 0.940 & 0.839 & 0.577 & 0.723 & 0.509 & 0.796 & 0.916 \\
\hline
\end{tabular}

Note: AVE = average variance extracted; $\mathrm{CR}$ = construct reliability; $\mathrm{SQ}$ = service quality; $\mathrm{TS}$ = trip satisfaction; $\mathrm{WOM}=$ word of mouth; TRR = tourist-resident relationship; $\mathrm{SP}$ = safety perception; Italic font = square-root of the AVE.

\subsection{Results of PLS Analysis}

Figure 2 shows the results of PLS analysis and Table 4 summarizes the results of PLS analysis that perceived service quality has significant positive effects on trip satisfaction and WOM, and trip 
satisfaction has a significant positive effect on WOM. The results also indicate that the tourist-resident relationship has a direct and positive effect on trip satisfaction. It also shows the moderating effects on the relationships between service quality and trip satisfaction and between trip satisfaction and WOM. The safety perception is shown to have a direct and positive effect on trip satisfaction and WOM. It also shows a moderating effect on the relationship between service quality and trip satisfaction. The values of R-squared of trip satisfaction and WOM are 0.636 and 0.728 , so a high percentage of variance is explained by the model. For the significant direct effects of the tourist-resident relationship and safety perception on trip satisfaction and WOM, the effect size f-Square values are ranged from 0.052 to 0.306 . These results indicate these effects are ranged from small to large effects [85]. For the significant moderating effects, the effect size f-Square values are ranged from 0.013 to 0.022 . These effects are counted as small effects [86].

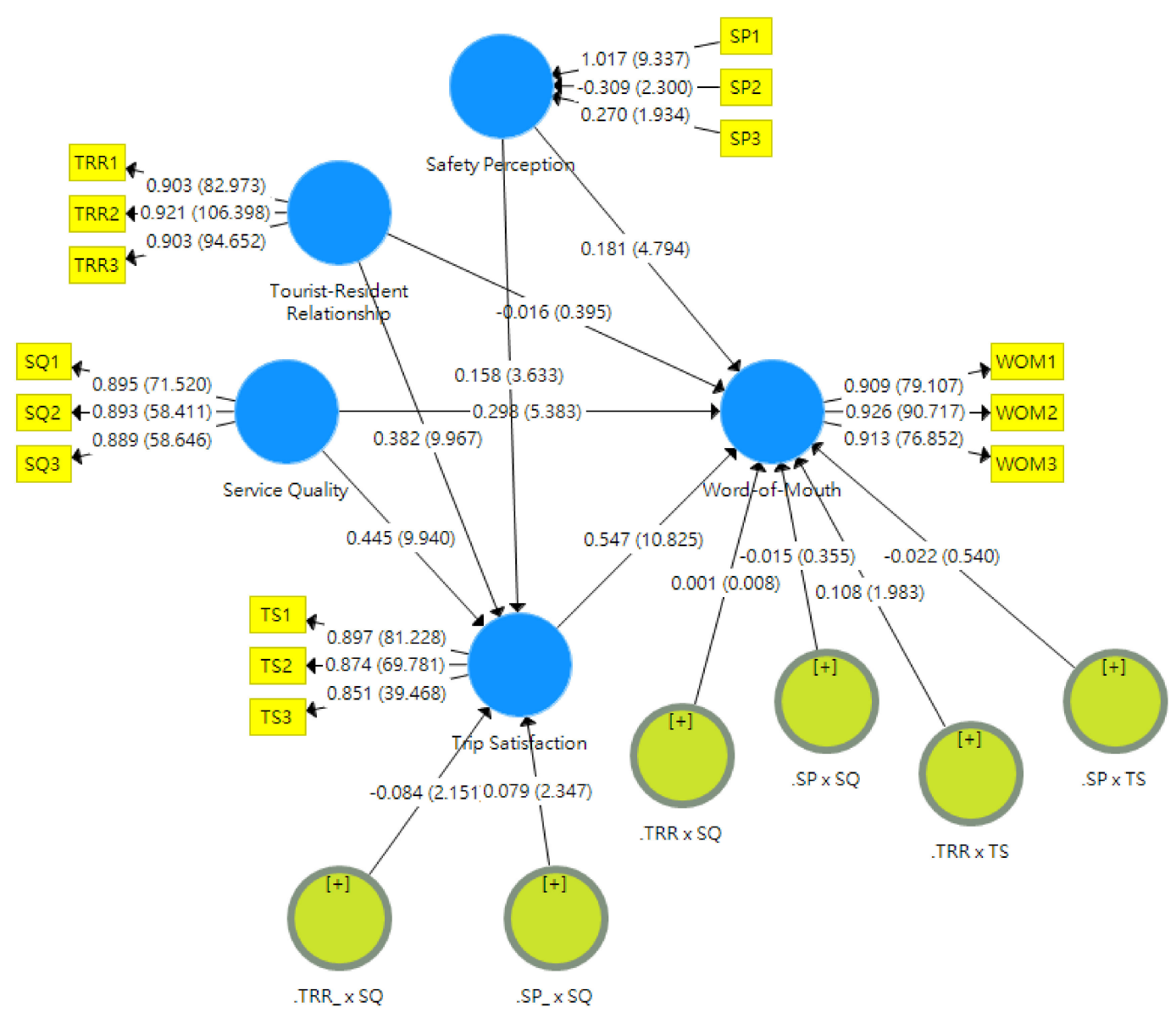

Figure 2. Results of PLS analysis.

Table 4. Results of PLS analysis.

\begin{tabular}{cccccc}
\hline & Coefficients & t-Statistic & f-Square & Hypothesis & Result \\
\hline $\mathrm{SQ} \rightarrow$ TS & $0.445^{* * *}$ & 9.940 & 0.306 & & \\
$\mathrm{SQ} \rightarrow$ WOM & $0.298^{* * *}$ & 5.383 & 0.128 & & \\
$\mathrm{TS} \rightarrow$ WOM & $0.547^{* * *}$ & 10.825 & 0.364 & & \\
$\mathrm{TRR} \rightarrow$ TS & $0.382^{* * *}$ & 9.967 & 0.306 & H1a & Accept \\
$\mathrm{TRR} \rightarrow$ WOM & $-0.016(\mathrm{~ns})$ & 0.395 & 0.001 & H1b & Reject \\
$\mathrm{SP} \rightarrow$ TS & $0.158^{* * *}$ & 3.633 & 0.052 & H2a & Accept \\
$\mathrm{SP} \rightarrow$ WOM & $0.181^{* * *}$ & 4.794 & 0.080 & H2b & Accept \\
$\mathrm{SQ} \times$ TRR $\rightarrow$ TS & $-0.084^{*}$ & 2.151 & 0.013 & H3a & Accept \\
\hline
\end{tabular}


Table 4. Cont.

\begin{tabular}{cccccc}
\hline & Coefficients & t-Statistic & f-Square & Hypothesis & Result \\
\hline $\mathrm{SQ} \times \mathrm{TRR} \rightarrow$ WOM & $0.001(\mathrm{~ns})$ & 0.008 & 0.000 & $\mathrm{H} 3 \mathrm{~b}$ & Reject \\
$\mathrm{TS} \times \mathrm{TRR} \rightarrow$ WOM & $0.108^{*}$ & 1.983 & 0.022 & $\mathrm{H} 3 \mathrm{c}$ & Accept \\
$\mathrm{SQ} \times \mathrm{SP} \rightarrow \mathrm{TS}$ & $0.079 *$ & 2.347 & 0.015 & $\mathrm{H} 4 \mathrm{a}$ & Accept \\
$\mathrm{SQ} \times \mathrm{SP} \rightarrow$ WOM & $-0.015(\mathrm{~ns})$ & 0.355 & 0.001 & $\mathrm{H} 4 \mathrm{~b}$ & Reject \\
$\mathrm{TS} \times \mathrm{SP} \rightarrow$ WOM & $-0.022(\mathrm{~ns})$ & 0.540 & 0.001 & $\mathrm{H} 4 \mathrm{c}$ & Reject \\
\hline
\end{tabular}

Note: (1) $\mathrm{SQ}=$ service quality; TS = trip satisfaction; $\mathrm{WOM}=$ word of mouth; TRR = tourist-resident relationship; $\mathrm{SP}=$ safety perception; $(2)^{* * *} p$-value $<0.001,{ }^{*} p$-value $<0.05$, ns-non-significant.

In order to understand the moderating effects of the tourist-resident relationship and safety perception, a simple slope analysis is performed and the results are shown in Figure 3. Figure 3a,c indicate that those tourists who have a high tourist-resident relationship or perceive high safety conditions are more satisfied with the trip than those who have a low tourist-resident relationship or who perceive low safety conditions when they experience the same level of tourism services. Figure $3 \mathrm{~b}$ indicates that those tourists who have positive trip satisfaction and perceive a high tourist-resident relationship would have a stronger intention to pass on by WOM favorable views to their friends and relatives than those who have a low tourist-resident relationship. Hence, H1a, H2a, H2b, H3a, H3c, and H4a are accepted.

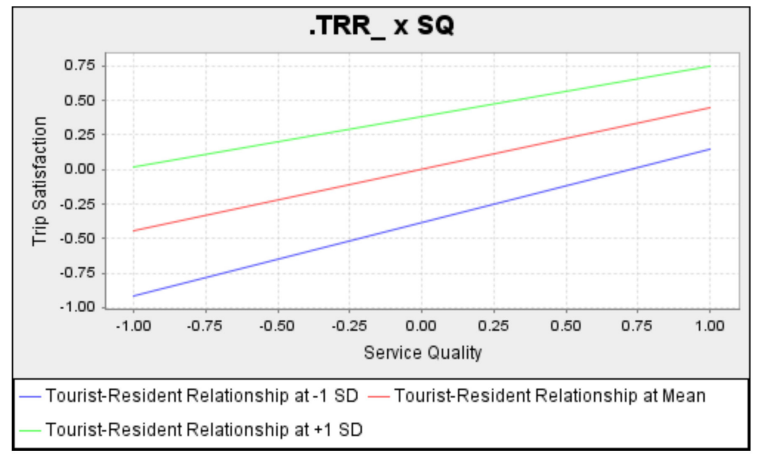

(a)

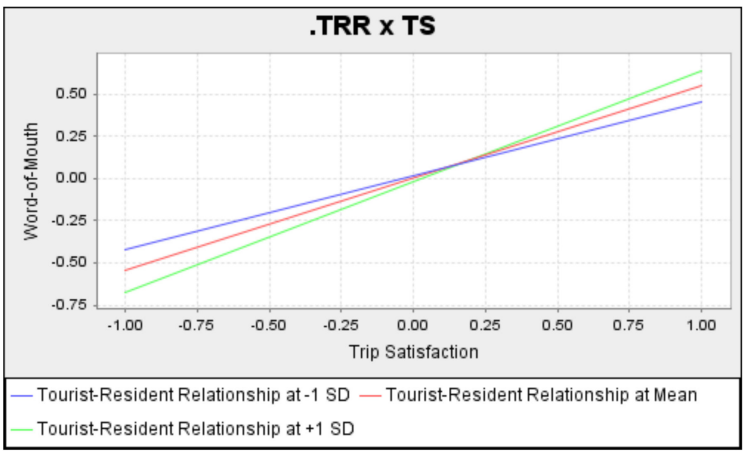

(b)

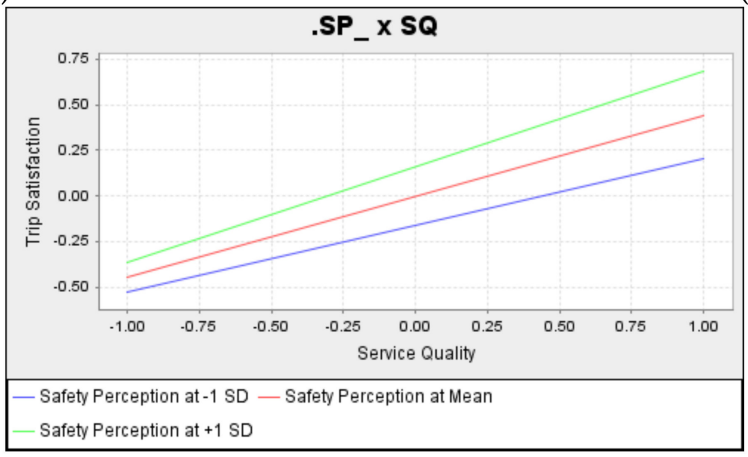

(c)

Figure 3. The moderating effects for tourist-resident relationship and safety perception. (a) the moderating effect of tourist-resident relationship on the relationship between service quality and trip satisfaction; (b) the moderating effect of tourist-resident relationship on the relationship between trip satisfaction and word-of-mouth; (c) the moderating effect of safety perception on the relationship between service quality and trip satisfaction.

\subsection{Further Analysis in Socio-Demographic Characteristics}

The PLS multi-group analysis (PLS-MGA) method is used to compare the effects of the tourist-resident relationship and safety perception on the relationship between service quality, trip satisfaction, and WOM recommendation among different groups of respondents. Only the 
groups larger than a hundred are selected to compare. The results of PLS-MGA indicate that there is no difference between different gender and age groups. Only the respondents whose income is 'USD3000 or above' show a higher effect of tourist-resident relationship on WOM recommendation than the group whose income is 'USD1000-2999' (path coefficients difference $=-0.161$, $p$-value $=0.978>0.950)$. However, the direct effects of the tourist-resident relationship on WOM recommendation for these two groups are not significant ( $p$-value $>0.05$ ), so this difference becomes less meaningful. There is no difference in the effect of safety perception on trip satisfaction and WOM recommendation in any groups of the respondents.

\section{Conclusions and Discussions}

\subsection{Conclusions}

This study has achieved its objective and successfully demonstrates the impacts of the tourist-resident relationship and safety perception on the relationship between service quality, trip satisfaction, and WOM recommendation. The results of the PLS analysis indicate that safety perception have significant effects on both trip satisfaction and WOM recommendation, and it positively moderates the relationship between service quality and trip satisfaction; the tourist-resident relationship affects trip satisfaction but not the WOM recommendation, negatively moderates the relationship between service quality and trip satisfaction, and positively moderates the relationship between trip satisfaction and WOM recommendation. Therefore, the tourist-resident relationship and safety perception are important factors for the sustainable growth of tourism in a destination. Although the results of PLS-MGA show that there is a significant difference between high-income and low-income groups in the effect of the tourist-resident relationship on WOM recommendation, the direct effects of the tourist-resident relationship on WOM recommendation for both groups are not significant as the results of total samples show. Therefore, it can be concluded that there is no difference in the effects of the tourist-resident relationship and safety perception on the relationship between service quality, trip satisfaction, and WOM recommendation among different socio-demographic groups of tourists.

\subsection{Theoretical Contributions}

'Sustainable tourism growth' is interpreted as a form of 'sustainable tourism development' $[87,88]$ and resolving sustainability issues in tourism development is an important area of tourism research. Most of the studies in the tourist-resident relationship were based on residents' perspective and explained how the tourist-resident relationship influences residents' attitude towards the support for tourism development of a destination $[2,89]$. Given the limited number of studies on the tourist-resident relationship from the tourist perspective in an urban context, we have limited knowledge concerning the effect of the tourist-resident relationship on tourist behavior. This study shows the roles played by the tourist-resident relationship in enhancing trip satisfaction and WOM with regard to a given urban destination. This finding shows the importance of building and retaining a good tourist-resident relationship in order to enhance a destination's sustainability. What is indicated here is that positive and negative tourist-resident relationships exist simultaneously in a given urban context. Social exchange theory typically examines how tourism impacts affect residents' support for tourism development [14] and also works well in studying sustainable rural tourism development $[90,91]$. However, the results of this study explain how tourists' perception of the tourist-resident relationship affects their behavior towards an urban destination which also has an impact on the tourism development in that destination. The tourist-resident relationship that tourists experienced not only affects their trip satisfaction but also moderates the relationship between trip satisfaction and their WOM recommendation. Such that even if tourists are satisfied with their trip in terms of the good quality of tourism services, such as transportation and accommodation, their WOM recommendation will be discounted in cases where they have experienced a poor tourist-resident relationship. As mentioned above, tourists like to interact with local people during the trip, but this 
interaction is a two-way social, cultural, and psychological exchange. The relationship between residents and tourists may be unequal and unbalanced and that may lead to different perspectives held by tourists and residents regarding this relationship, but, the best means of improving the tourist-resident relationship should be to consider all actors' (both tourists and residents') perspectives since all actors are engaged in present and future interpersonal exchanges. This study provides a good reference point with which to explore tourists' behaviors as a consequence of social, cultural, and psychological exchanges at an urban destination.

As discussed above, safety is clearly a pressing concern for tourists and it is mentioned repeatedly in the literature; however, most of the previous studies only surveyed the samples regarding their perception of safety from the media when planning a trip [5]. Comparatively little attention has been paid to the behavior of tourists in respect of their perception of safety experienced during a visit to an urban destination. Although few studies found that safety is a choice of a behavioral attribute which influences tourists' "repeat visitation" [92,93], few studies have illustrated the relationship between the perception of safety and tourist satisfaction. The results of this study confirm that a tourist who has a better perception of safety exhibits a higher level of satisfaction and also indicate that a tourist who has a good experience in terms of personal safety with regard to an urban destination would be more willing to provide a positive WOM recommendation. Furthermore, this study clarifies the moderating role of safety perception on service quality and trip satisfaction. It means that a tourist who received a certain level of tourism service will more be satisfied with the trip in cases where he/she experienced a good perception of destination safety. The results of this study enrich our knowledge of the implications of tourists' perception of safety with regard to urban destinations.

This study also contributes to the use of survey questions and research design, as well to the development of a research model for studying the moderating effects of the relationship between service quality, customer satisfaction, and customer loyalty. Three measurable items were used concerning respondents' perception of residents' closeness (contact, show friendliness, and interact) for measuring the tourist-resident relationship in this study. Additionally, three measurable items about respondents' judgment in three key unsafe events (crime, violence and terrorism) in an urban destination for measuring the perception of safety were developed and tested. This study provides useful measurement scales for researchers to conduct future research.

\subsection{Practical Implications}

Tourists who perceived a good tourist-resident relationship are more likely to be satisfied with a trip and will have a higher level of intention to circulate positive views via WOM. It is suggested that governments, including in particular the government of Macau, should raise the profile of policies that promote good resident-tourist relationships as this clearly has an influence on the sustainability of tourism. This is a pressing concern in Macau given the industry's importance in this respect. Residents are clearly aware that tourism is an important aspect of the local economy, but they worry about the negative effects on their community, and over time this may increase the negative aspects of resident-tourist relations to the detriment of the industry. There are a number of tourism management strategies that could be introduced to avert these perceived negative impacts, including zoning, more effective signage, enhanced cultural awareness of the cultural heritage of the city and more effective policing, including forms of tourism policing that have been introduced elsewhere.

Serious tensions have arisen between tourists and residents because tourists are drawn from diverse sources and may not be conversant with local norms of behaviour and in cases of conflict may become a target for local grievances. There could also be a geographical issue whereas some small destinations in Asia such as Macau have limited space and can easily become crowded. Therefore, tourism development planners may consider building attraction points and retail outlets that are far away from the communities in order to spread the tourists out geographically from the central areas of the city. 
It would also be useful to look more closely into the mindset of tourists. Special attention should be paid to those tourists who felt safe and satisfied with their visit to understand more clearly and precisely the factors that helped to generate those feelings. This would also help residents to work together to reduce security risks for tourists in order to underpin a destination's safe image in order to attract and encourage more visitors and repeat visitation. On the other hand, travel agents and tour guides could educate tourists on how to be more mindful of security matters. Because tourism activities such as sightseeing, shopping, and dining are often group activities, tourists can help each other to protect their valuables.

\subsection{Limitations and Further Studies}

This survey was conducted in Macau and it is difficult to generalize to other urban destinations as this Special Administrative Region of China has its own particular culture and a distinctive relationship with the source of the majority of its tourists, China. Further research in other urban destinations is recommended.

In order to reduce the non-response bias due to time pressure, three questions were used for each construct. However, this type of scale may be insufficient. Researchers may consider employing attitude-based measures for rating service quality and qualitative techniques for measuring satisfaction in their further studies.

This study only investigated the moderating effects of the tourist-resident relationship and perception of safety with regard to the relationship between service quality, trip satisfaction, and WOM concerning this urban destination. However, previous studies have identified other factors that also influence trip satisfaction and WOM in urban contexts such as perceived value [8]. It would be worthwhile examining comprehensively how the tourist-resident relationship and perception of safety moderate the effects of other motives and tourist behaviors.

Author Contributions: I.K.W.L. contributed to research design, data analysis, and manuscript writing. M.H. provided efforts in manuscript writing. D.L. and Y.L. undertook project management, wrote the manuscript, and provided quality assurance of the research. All authors read and approved the final manuscript.

Funding: This research is supported by Sichuan Social Science Planning Fund Program (Grant No. SC17B077), Sichuan Science and Technology Support Project (Grant No. 2018ZR0124), Chengdu Social Science Planning Fund Program (Grant No. 2018L07), and Sichuan Education Bureau Research Found (Grant No. 16SA0014).

Conflicts of Interest: The authors declare no conflict of interest.

\section{References}

1. McCartney, G.; Lei, W.W.I. House of Cards-An analysis of Macao's resident support for tourism and casino development. Tour. Hosp. Res. 2016, 16, 144-157. [CrossRef]

2. Lai, I.K.W.; Hitchcock, M. Local reactions to mass tourism and community tourism development in Macau. J. Sustain. Tour. 2017, 25, 451-470. [CrossRef]

3. Hua, Y.; Yoo, J.J. Travel motivations of Mainland Chinese travelers to the United States. J. China Tour. Res. 2011, 7, 355-376. [CrossRef]

4. Mansfeld, Y.; Pizam, A. Toward a theory of tourism security. In Tourism, Security and Safety: From Theory to Practice; Mansfeld, Y., Pizam, A., Eds.; Elsevier, Butterworth-Heinemann: Burlington, MA, USA, 2006; pp. 1-28.

5. Adeloye, D.; Brown, L. Terrorism and domestic tourist risk perceptions. J. Tour. Cult. Chang. 2018, 16, $217-233$. [CrossRef]

6. Tham, A.; Croy, G.; Mair, J. Social media in destination choice: Distinctive electronic word-of-mouth dimensions. J. Travel Tour. Mark. 2013, 30, 144-155. [CrossRef]

7. Tasci, A.D.A.; Gartner, W.C. Destination image and its functional relationships. J. Travel Res. 2007, 45, 413-425. [CrossRef]

8. Phillips, W.M.J.; Wolfe, K.; Hodur, N.; Leistritz, F.L. Tourist word of mouth and revisit intentions to rural tourism destinations: A case of North Dakota, USA. Int. J. Tour. Res. 2013, 15, 93-104. [CrossRef] 
9. Doxey, G.V. A causation theory of visitor-resident irritants: Methodology and research inferences. In Proceedings of the Sixth Annual Conference on Travel and Tourism Research Associations, San Diego, CA, USA, 8-11 September 1975; pp. 195-198.

10. Moyle, B.D.; Weiler, B.; Croy, G. Visitors' perceptions of tourism impacts: Bruny and Magnetic Islands, Australia. J. Travel Res. 2013, 52, 392-406. [CrossRef]

11. Hunter, C. Sustainable tourism as an adaptive paradigm. Ann. Tour. Res. 1997, 24, 850-867. [CrossRef]

12. Snepenger, D.J.; Murphy, L.; O'Connell, R.; Gregg, E. Tourists and residents use of a shopping space. Ann. Tour. Res. 2003, 30, 567-580. [CrossRef]

13. Hughes-Freeland, F. Packaging dreams: Javanese perceptions of tourism and performance. In Tourism in Southeast Asia; Hitchcock, M., King, V.T., Parnwell, M.J.G., Eds.; Routledge: London, UK, 1993; pp. 138-154.

14. Ap, J. Residents' perceptions on tourism impacts. Ann. Tour. Res. 1992, 19, 665-690. [CrossRef]

15. Ekrem, T.F.E.; Huseyin, O.; Sedat, Z. Resident attitudes toward tourism impacts: The case of Kusadasi in Turkey. Int. J. Hosp. Tour. Adm. 2002, 3, 79-100.

16. Lindberg, K.; Johnson, R.L. Modeling resident attitudes toward tourism. Ann. Tour. Res. 1997, $24,402-424$. [CrossRef]

17. McCool, S.F.; Martin, S.R. Community attachment and attitudes toward tourism development. J. Travel Res. 1994, 32, 29-34. [CrossRef]

18. Ross, G.F. Resident perceptions of the impact of tourism on an Australian city. J. Travel Res. 1992, 30, 13-20. [CrossRef]

19. Liu, J.C.; Var, T. Resident attitudes toward tourism impacts in Hawaii. Ann. Tour. Res. 1986, 13, $193-214$. [CrossRef]

20. Siu, G.; Lee, L.Y.S.; Leung, D. Residents' perceptions toward the "Chinese tourists' wave" in Hong Kong: An exploratory study. Asia Pac. J. Tour. Res. 2013, 18, 446-463. [CrossRef]

21. Hsieh, C.M.; Park, S.H.; Huh, C. A Comparison Model of Residents' and Tourists' Attitudes toward Sustainable Tourism Development: A Case of Penghu Island in Taiwan. Tourism Travel and Research Association: Advancing Tourism Research Globally. 2016. Available online: http://scholarworks.umass. edu/ttra/2010/Oral/11 (accessed on 29 May 2018).

22. United Nations Environment Programme and World Tourism Organization. Making Tourism More Sustainable-A Guide for Policy Makers. 2005. Available online: http:/ /www.unep.fr/shared/publications / pdf/DTIx0592xPA-TourismPolicyEN.pdf (accessed on 20 May 2018).

23. Hassan, S.S. Determinants of Market Competitiveness in an Environmentally Sustainable Tourism Industry. J. Travel Res. 2000, 38, 239-245. [CrossRef]

24. Prashyanusorn, V.; Kaviya, S.; Yupapin, P. Surveillance system for sustainable tourism with safety and privacy protection. Procedia Soc. Behav. Sci. 2010, 2, 74-78. [CrossRef]

25. Ryan, C. Crime, violence, terrorism and tourism: An accidental or intrinsic relationship? Tour. Manag. 1993, 14, 173-183. [CrossRef]

26. Mekinc, J.; Cvikl, H. The structure of security and safety crises in tourism. J. Tour. Serv. 2013, 4, 38-50.

27. Seabra, C.; Dolnicar, S.; Abrantes, J.L.; Kastenholz, E. Heterogeneity in risk and safety perceptions of international tourists. Tour. Manag. 2013, 36, 502-510. [CrossRef]

28. Neumayer, E. The impact of political violence on tourism: Dynamic cross-national estimation. J. Confl. Resolut. 2004, 48, 259-281. [CrossRef]

29. Elliott, J. Mexico Cartel Clashes Worry Canadian Tourists. CTVNew.ca Published Tuesday, 5 May 2015 10:44AM EDT. 2015. Available online: http://www.ctvnews.ca/canada/mexico-cartel-clashes-worrycanadian-tourists-1.2359460 (accessed on 20 May 2018).

30. Pizam, A. A comprehensive approach to classifying acts of crime and violence at tourism destinations. J. Travel Res. 1999, 38, 5-12. [CrossRef]

31. Zerva, K. Crime and tourism: Organizational opportunities and social marketing in LA Gang Tours. J. Tour. Cult. Chang. 2013, 11, 92-108. [CrossRef]

32. George, R. Tourist's perceptions of safety and security while visiting Cape Town. Tour. Manag. 2003, 24, 575-585. [CrossRef]

33. Brunt, P.; Mawby, R.; Hambly, Z. Tourist victimization and the fear of crime on holiday. Tour. Manag. 2000, 21, 417-424. [CrossRef] 
34. Owusu-Frimpong, N.; Nwankwo, S.; Blankson, C.; Tarnanidis, T. The effect of service quality and satisfaction on destination attractiveness of sub-Saharan African countries: The case of Ghana. Curr. Issues Tour. 2013, 16, $627-646$. [CrossRef]

35. Sun, L.B.; Qu, H. Is there any gender effect on the relationship between service quality and word-of-mouth? J. Travel Tour. Mark. 2011, 28, 210-224. [CrossRef]

36. Fakharyan, M.; Omidvar, S.; Khodadadian, M.R.; Jalilvand, M.R.; Nasrolahi Vosta, L. Examining the effect of customer-to-customer interactions on satisfaction, loyalty, and word-of-mouth behaviors in the hospitality industry: The mediating role of personal interaction quality and service atmospherics. J. Travel Tour. Mark. 2014, 31, 610-626. [CrossRef]

37. Cho, H.S.; Byun, B.; Shin, S. An Examination of the Relationship between Rural Tourists' Satisfaction, Revisitation and Information Preferences: A Korean Case Study. Sustainability 2014, 6, 6293-6311. [CrossRef]

38. Baker, D.A.; Crompton, J.L. Quality, satisfaction and behavioral intentions. Ann. Tour. Res. 2000, $27,785-804$. [CrossRef]

39. White, C.J. The impact of emotions on service quality, satisfaction, and positive word-of-mouth intentions over time. J. Mark. Manag. 2010, 26, 381-394. [CrossRef]

40. Parasuraman, A.; Zeithaml, V.A.; Berry, L.L. A conceptual model of service quality and its implications for future research. J. Mark. 1985, 49, 41-50. [CrossRef]

41. Lai, I.K.W.; Hitchcock, M.; Yang, T.; Lu, T.W. Literature review on service quality in hospitality and tourism (1984-2014): The future directions and trends. Int. J. Contemp. Hosp. Manag. 2018, 20, 114-159. [CrossRef]

42. Kouthouris, C.; Alexandris, K. Can service quality predict customer satisfaction and behavioral intentions in the sport tourism industry? An application of the SERVQUAL model in an outdoors setting. J. Sport Tour. 2005, 10, 101-111. [CrossRef]

43. Chen, C.M.; Lee, H.T.; Chen, S.H.; Huang, T.H. Tourist behavioral intentions in relation to service quality and customer satisfaction in Kinmen National Park, Taiwan. Int. J. Tour. Res. 2011, 13, 416-432. [CrossRef]

44. Ye, Q.; Li, H.; Wang, Z.; Law, R. The influence of hotel price on perceived service quality and value in e-tourism: An empirical investigation based on online traveller reviews. J. Hosp. Tour. Res. 2014, 38, $23-39$. [CrossRef]

45. Díaz, R.M.; Rodríguez, E.T.F.; Díaz, R.R. A model of market positioning based on value creation and service quality in the lodging industry: An empirical application of online customer reviews. Tour. Econom. 2015, 21, 1273-1294. [CrossRef]

46. Lai, I.K.W. The roles of value, satisfaction, and commitment in the effect of service quality on customer loyalty in Hong Kong-style tea restaurants. Cornell Hosp. Quart. 2015, 56, 118-138. [CrossRef]

47. Cronin, J.J., Jr.; Brady, M.K.; Hult, G.T.M. Assessing the effects of quality, value, and customer satisfaction on consumer behavioral intentions in service environments. J. Retail. 2000, 76, 193-218. [CrossRef]

48. Richins, M.L. Negative word-of-mouth by dissatisfied consumers: A pilot study. J. Mark. 1983, 47, 68-78. [CrossRef]

49. Bloemer, J.; de Ruyter, K.; Wetzels, M. Linking perceived service quality and service loyalty: A multidimensional perspective. Eur. J. Mark. 1999, 33, 1082-1106. [CrossRef]

50. Bramwell, B.; Lane, B. Sustainable Tourism: An Evolving Global Approach. J. Sustain. Tour. 1993, 1, 1-5. [CrossRef]

51. Pappu, R.; Quester, P. Does customer satisfaction lead to improved brand equity? An empirical examination of two categories of retail brands. J. Prod. Brand Manag. 2006, 15, 4-14. [CrossRef]

52. Cronin, J.J.; Taylor, S.A. Measuring service quality: A reexamination and extension. J. Mark. 1992, 56, 55-68. [CrossRef]

53. Anderson, E.W.; Fornell, C.; Lehmann, D.R. Customer satisfaction, market share and profitability. J. Mark. 1994, 58, 53-66. [CrossRef]

54. Oliver, R.L. Satisfaction: A Behavioral Perspective on the Consumer; McGraw-Hill: New York, NY, USA, 1997.

55. Bloemer, J.; Odekerken-Schroder, G. Store satisfaction and store loyalty explained by customer- and store-related factors. J. Cust. Satisf. Dissatisfaction Complain. Behav. 2002, 15, 68-80.

56. UNWTO. Sustainable Development of Tour. Available online: http://sdt.unwto.org/content/about-us-5 (accessed on 26 October 2017).

57. Meng, S.M.; Liang, G.S.; Yang, S.H. The relationships of cruise image, perceived value, satisfaction and post-purchase behavioral intention on Taiwanese tourists. Afr. J. Bus. Manag. 2011, 5, 19-29. 
58. Okello, M.M.; Yerian, S. Tourist Satisfaction in Relation to Attractions and Implications for Conservation in the Protected Areas of the Northern Circuit, Tanzania. J. Sustain. Tour. 2009, 17, 605-625. [CrossRef]

59. Var, T.; Beck, R.A.D.; Loftus, P. Determination of tourism attractiveness of the touristic areas in British Columbia. J. Travel Res. 1997, 15, 23-39. [CrossRef]

60. Hse, C.H.C.; Cai, L.A.; Li, M. Expectation, motivation, and attitude: A tourist behavioral model. J. Travel Res. 2010, 49, 282-296. [CrossRef]

61. Su, M.M.; Long, Y.; Wall, G.; Jin, M. Tourist-community interactions in ethnic tourism: Tuva villages, Kanas Scenic Area, China. J. Tour. Cult. Chang. 2016, 14, 1-26. [CrossRef]

62. Pizam, A.; Tarlow, P.E.; Bloom, J. Making tourists feel safe: Whose responsibility is it? J. Travel Res. 1997, 36, $23-28$. [CrossRef]

63. Tasci, A.D.A.; Boylu, Y. Cultural comparison of tourists' safety perception in relation to trip satisfaction. Int. J. Tour. Res. 2010, 12, 179-192. [CrossRef]

64. Yoon, Y.; Uysal, M. An examination of the effects of motivation and satisfaction on destination loyalty: A structural model. Tour. Manag. 2005, 26, 45-56. [CrossRef]

65. Sinkovics, R.R.; Penz, E. Social distance between residents and international tourists-Implications for international business. Int. Bus. Rev. 2009, 18, 457-469. [CrossRef]

66. Mechinda, P.; Serirat, S.; Gulid, N. An examination of tourists' attitudinal and behavioral loyalty: Comparison between domestic and international tourists. J. Vacat. Mark. 2009, 15, 129-148. [CrossRef]

67. Moorthy, S.; Ratchford, B.T.; Talukdar, D. Consumer information search revisited: Theory and empirical analysis. J. Consum. Res. 1997, 23, 263-277. [CrossRef]

68. Bitner, M.J. Evaluating service encounters: The effects of physical surroundings and employee responses. J. Mark. 1990, 54, 69-82. [CrossRef]

69. Narayan, B.; Rajendran, C.; Prakash Sai, L. Scales to measure and benchmark service quality in tourism industry. Benchmark. Int. J. 2008, 15, 469-493. [CrossRef]

70. Vogel, M.; Pettinari, J. Personal safety and transit paths, environments, stops and stations. In Final Report Centre for Transportation Studies; Center for Transporation Studies: Minneapolis, MN, USA, 2002.

71. Babin, B.J.; Lee, Y.K.; Kim, E.J.; Griffin, M. Modeling consumer satisfaction and word-of-mouth: Restaurant patronage in Korea. J. Serv. Mark. 2005, 19, 133-139. [CrossRef]

72. Chang, S.J.; van Witteloostuijn, A.; Eden, L. From the editors: Common method variance in international business research. J. Int. Bus. Stud. 2010, 41, 178-184. [CrossRef]

73. DSEC, 2016 Statistics Reports, Statistics and Census Service. Government of Macao Special Administrative Region. 2016. Available online: http:/ /www.dsec.gov.mo/default.aspx?noredirect=true (accessed on 20 May 2018).

74. Macao Tourism Data Plus, Tourism Statistics. Government of Macao Special Administrative Region. 2018. Available online: http:/ / mtdplus.macaotourism.gov.mo (accessed on 20 May 2018).

75. Wan, Y.K.P.; Li, X. Sustainability of tourism development in Macao, China. Int. J. Tour. Res. 2013, 15, 52-65. [CrossRef]

76. Li, X.; Wan, Y.K.P. Residents' attitudes toward tourism development in Macao: A path model. Tour. Anal. 2013, 18, 443-455. [CrossRef]

77. Ringle, C.M.; Wende, S.; Becker, J.M. SmartPLS 3. Boenningstedt: SmartPLS GmbH, 2015. Available online: http:/ / www.smartpls.com (accessed on 20 May 2018).

78. Haenlein, M.; Kaplan, A.M. A beginner's guide to partial least square analysis. Underst. Stat. 2004, 3, $283-297$. [CrossRef]

79. Hair, J.F., Jr.; Black, W.C.; Babin, B.J.; Anderson, R.E. Multivariate Data Analysis, 7th ed.; Prentice-Hall Inc.: Englewood Cliffs, NJ, USA, 2010.

80. Lee, H.; Choi, S.Y.; Kang, Y.S. Formation of e-satisfaction and repurchase intention: Moderating roles of computer self-efficacy and computer anxiety. Expert Syst. Appl. 2009, 36, 7848-7859. [CrossRef]

81. Hair, J.F., Jr.; Ringle, C.M.; Sarstedt, M. PLS-SEM: Indeed a silver bullet. J. Mark. Theory Pract. 2011, 19, $139-151$. [CrossRef]

82. Hair, J.F., Jr.; Sarstedt, M.; Ringle, C.M.; Mena, J.A. An assessment of the use of partial least squares structural equation modeling in marketing research. J. Acad. Mark. Sci. 2012, 40, 414-433. [CrossRef]

83. do Valle, P.O.; Assaker, G. Using partial least squares structural equation modeling in tourism research: A review of past research and recommendations for future applications. J. Travel Res. 2016, 55, 695-708. [CrossRef] 
84. Diamantopoulos, A.; Winklhofer, H.M. Index construction with formative indicators: An alternative to scale development. J. Mark. Res. 2001, 38, 269-277. [CrossRef]

85. Cohen, J. Statistical Power Analysis for the Behavioral Sciences, 2nd ed.; Lawrence Erlbaum Associates: Hillsdale, NJ, USA, 1988.

86. Hair, J.F.; Hult, G.T.M.; Ringle, C.M.; Sarstedt, M. A Primer on Partial Least Squares Structural Equation Modeling (PLS-SEM), 2nd ed.; Sage: Thousand Oaks, CA, USA, 2017.

87. Monbiot, G. How Sustainability Became "Sustained Growth". 2012. Available online: http:/ / www.monbiot. com/2012/06/22/how-sustainability-became-sustained-growth/ (accessed on 20 May 2018).

88. Bramwell B, L.B. Sustainable tourism: An evolving global approach. J. Sustain. Tour. 1993, 1, 1-5. [CrossRef]

89. Tanja, A.; Dragicevic, V.; Pejović, L. Interaction between tourists and residents: Influence on tourism development. Pol. Sociol. Rev. 2011, 173, 107-118.

90. Zhu, H.; Liu, J.; Wei, C.; Li, W.; Wang, L. Residents' attitudes towards sustainable tourism development in a historical-cultural village: Influence of perceived impacts, sense of place and tourism development potential. Sustainability 2017, 9, 61. [CrossRef]

91. Muresan, I.C.; Oroian, C.F.; Harun, R.; Arion, F.H.; Porutiu, A.; Chiciudean, G.O.; Todea, A.; Lile, R. Local residents' attitude toward sustainable rural tourism development. Sustainability 2016, 8, 100. [CrossRef]

92. Chen, J.S.; Gursoy, D. An investigation of tourists' destination loyalty and preferences. Int. J. Contemp. Hosp. Manag. 2001, 13, 79-85. [CrossRef]

93. George, R.; Swart, K. Tourists' perceptions of London, United Kingdom (UK), as a safe host city during the 2012 Olympic Games. J. Travel Tour. Mark. 2015, 32, 1117-1132. [CrossRef]

(C) 2018 by the authors. Licensee MDPI, Basel, Switzerland. This article is an open access article distributed under the terms and conditions of the Creative Commons Attribution (CC BY) license (http:/ / creativecommons.org/licenses/by/4.0/). 